COLLABORATIVE CREATIVITY IN AD HOC VIRTUAL TEAMS: TESTING AND EVALUATING THE ACCEPTANCE AND USABILITY OF SELECTED CREATIVITY TECHNIQUES IN A VIRTUAL WORKSPACE

CRIATIVIDADE COLABORATIVA EM EQUIPES VIRTUAIS AD HOC: TESTE E AVALIAÇÃO DA ACEITAÇÃO E DA USABILIDADE DE TÉCNICAS DE CRIATIVIDADE SELECIONADAS EM UM ESPAÇO DE TRABALHO VIRTUAL

\title{
Anke Herodek
}

Bachelor of Arts in Communication and Event (MICE) Management from IST - University of Applied Sciences (Düsseldorf/ Germany). Master Student in Business Transformation Management at IST - University of Applied Sciences (Düsseldorf/ Germany).

E-mail: anke.herodek@gmail.com

\section{Answin Vilmar}

Doctor in Economics from Technical University Berlin (Berlin/Germany), Professor at IST - University of Applied Sciences

(Düsseldorf/Germany).

E-mail: avilmar@ist-hochschule.de 


\section{Brazilian

\section{ABSTRACT}

Creativity in the context of marketing and as the prerequisite of innovation is a group achievement, not merely a solitary feat. Whereas "group" in the past meant convening in one place, using tools and techniques to be creative together, it recently evolved into meet-ing in virtual places, sometimes with complete strangers, working together to achieve a shared goal, using state-of-the-art information and communication technologies. What stays the same is the need to use creativity techniques, to try to trigger and enhance individual and collaborative creativity, and to gather a greater number of ideas in a short time. This article addresses the acceptance and usability of some of the most popular creativity techniques for virtual ideation in a digital workspace, as well as prominent inhibiting and enhancing factors to virtual creative teamwork. In a laboratory experiment, three selected creativity techniques were tested and the participants were afterwards interviewed about their experiences via an anonymous online survey. The results indicate that creative collaboration is possible and effective also in virtual ad hoc teams. The techniques tested were easily applied and general-ly accepted by the participants and yielded numerous ideas.

Keywords: Collaborative creativity. Virtual ad hoc teams. Creativity techniques. Experimental design. Ideation session.

\section{RESUMO}

A criatividade no contexto do marketing e como pré-requisito da inovação é uma conquista do grupo, não apenas um feito solitário. Enquanto "grupo" no passado significava reunir-se em um lugar, usando ferramentas e técnicas para serem criativos juntos, recentemente evoluiu para encontros em lugares virtuais, às vezes com completos estranhos, trabalhando juntos para alcançar um objetivo comum, usando o estado de tecnologias de informação e comunicação de última geração. O que permanece igual é a necessidade de usar técnicas de criatividade, para tentar desencadear e potencializar a criatividade individual e colaborativa, e para reunir um maior número de ideias em um curto espaço de tempo. Este artigo aborda a aceitação e a usabilidade de algumas das técnicas de criatividade mais populares para a ideação virtual em um espaço de trabalho digital, bem como os fatores inibidores e aprimoradores proeminentes para o trabalho em equipe criativo virtual. Em um experimento de laboratório, três técnicas de criatividade selecionadas foram testadas e os participantes foram entrevistados sobre suas experiências por meio de uma pesquisa online anônima. Os resultados indicam que a colaboração criativa é possível e eficaz também em equipes ad hoc virtuais. As técnicas testadas foram facilmente aplicadas e geralmente aceitas pelos participantes e geraram inúmeras idéias.

Palavras-chave: Criatividade colaborativa. Equipes ad hoc virtuais. Técnicas de criatividade. Design experimental. Sessão de ideação. 


\section{Brazilian

\section{INTRODUCTION}

All through history creativity has sparked innovation and therefore enabled the evolution of society. Ness et al. state that ideas are co-constructed in social interactions between the social and the individual. "Humans exist and develop in intellectual interdependence and social interaction" (NESS; DYSTHE, 2020, p. 31).

Continuous innovation in ever shorter product-life-cycles is indeed the key to success and survival for businesses. Or as Furmanek \& Daurer put it: "Research satisfies a strong business need" (FURMANEK; DAURER, 2019, p. 1847). What applies to companies in general, applies in particular to providers in the creative industries, such as agencies, design offices, film studios, creative consultants and suppliers etc.

Very often sudden issues emerge, demanding immediate solutions without enough time for carefully framing questions, seeking solutions, testing, and iteration. Teams have to form quickly, collaborate, ideate and innovate, and disband as easily.

As a problem emerges, creative teams need to get working as quickly as possible with no time to wait for creativity and insight to find them, but rather to actively seek it out by using creativity techniques to widen individual perception as well as step outside the comfortable and well-used tracks of thinking and find out-of-the-box-solutions more quickly.

Creativity techniques are useful to stretch the range of perception of individuals, to challenge potentially limited ways of thinking, and even encourage complete new ways to seek inspiration and ideate. Essential to free, open, and confident ideation is a sense of trust within a team, sometimes also referred to as psychological security. The security to feel confident to voice ideas freely, and trust the other team members to actively and productively cooperate. In ad hoc teams, trust might be replaced with concepts such as Swift Trust. The question of whether or to what extent the creativity techniques originally developed for the analogue world are also suitable for virtual applications has gained enormous relevance, especially in the recent past. This question will be investigated as part of a larger research project by means of an experiment.

\section{RESEARCH GAP AND FOCUS}

Since creativity moved into organizational focus with being identified as key to innovation, a considerable amount of recent research is focused on trying to identify the enablers and inhibitors of creativity in corporations, mainly focusing on product development and innovation (FURMANEK; DAURER, 


\section{Brazilian \\ Creative Industries}

2019, pp. 1846). Typical for these organizations are long-term oriented design teams, often dispersed globally and therefore well experienced in virtual collaboration.

Less research has been conducted in small and medium-sized companies and the category of shortlived creative teams like groups of experts from different fields of expertise brought together for a singular project or to tackle an interdisciplinary problem, referred to as ad hoc teams (ADAMS et al., 2007, p. 2).

The focus of this work is on diverse, virtual ad hoc teams, as well as on the environmental aspects that impact creativity (AMABILE, 1996, p. 5), enabling collaborative creativity in virtual teams. This also includes the creation of a virtual space that enables shared creativity, allowing to build upon the ideas of others. The workspace not only consists of a work-platform to convene and collaborate, but also requires techniques to stimulate and cooperate on a given topic.

Although several attempts were made to classify creativity techniques (GAWLAK, 2014; GESCHKA, 2006; LEOPOLDINO et al., 2016; NEMIRO, 2008; TORRES-CORONAS; GASCO-HERNANDEZ, 2008), no consensus was found, leaving it to the practitioners' experience to decide which technique to use to reach the defined goal. To support research on creativity techniques in digital workspaces, the aim of this research as part of a greater research project is a practical test of selected popular creative techniques and individual evaluation with test candidates concerning usability and perceived support of group creativity.

This leads to the research question to be answered within this article:

RQ: Are currently known and established creativity techniques also usable and suitable for ad hoc virtual teams?

Within the context of the process of virtual team creativity, emphasis will therefore be put on the ideation part and its outcome. The basic assumption of this work is, that ideation in ad hoc virtual teams depends on the creative technique used, but is at least as efficient as in co-located teams.

Based on current literature, exemplary creativity techniques were examined and categorized regarding their approaches and required ways of thinking. As a result, the following hypotheses were deduced:

H1a: Creativity techniques based on different cognitive methods and approaches yield different numbers of unique ideas.

H1b: Creativity techniques based on different cognitive methods and approaches result in varying degrees of acceptance.

A major inhibiting factor in co-located creative sessions is the occurrence of production blocking. Creative sessions in virtual teams can be conducted by applying a virtual whiteboard. This results in the following hypothesis:

H2: In virtual team-ideation using a digital whiteboard, production-blocking is non-existent. 


\section{Brazilian \\ Creative Industries}

As teams are considered to be more than just the sum of their individual parts, a major benefit of team ideation is the possibility to build on the ideas of other team members. Considering the main characteristic of an ad hoc team being relative anonymity, as well as being less visible concludes in a sense of less responsibility to the outcome of the ideation session, the following hypothesis is derived:

\section{H3: Building on team members' ideas is less apparent in virtual ad hoc teams.}

\section{VIRTUAL TEAMS AND DIGITAL COLLABORATION}

In an increasingly global world, virtual teams (VT) offer organizations a maximum of flexibility in choosing the best talents exactly when and where needed for any specific project or task (JARVENPAA; LEIDNER, 1999, p. 791). Modern information and communication technology (ICT) enables the synchronous and asynchronous sharing of information, and working independently across time-zones and borders.

Other than co-located teams, VT are understood as a group of people, that are geographically and/ or organizationally dispersed, working with a shared purpose to accomplish a specified task, using ICT to collaborate (BJØRN; NGWENYAMA, 2009; MADUKA et al., 2018).

Literature has shown that the assembling of teams, as well as the teamwork itself, has grown increasingly dynamic, driven by demand. Adams defines ad hoc teams as groups of experts "brought together for a single purpose, project, or task" (ADAMS et al., 2007, p. 2). Contrary to long-term oriented teams, these ad hoc teams do not share a common history with a developed sense of trust in each other.

\subsection{TRUST IN VT AS GROUNDWORK FOR RELEVANT RESULTS}

Trust is considered to be the core precondition for effective cooperation in VT. Although it is hard to achieve as it takes time and ongoing exchange and communication, at the same time it is fundamental to create psychological safety within the team. Trust is essential for open discussion and effective collaboration to happen (DAIM et al., 2012, p. 204). According to the model of "Levels of collaboration" (BEYERLEIN et al., 2018, p. 208), collaboration is based on a shared understanding of the goals at hand, but also a shared understanding of the skills, abilities, and personalities (including gaps) of the team members (BEYERLEIN et al., 2018, p. 210), accumulated with time spent as a team.

Instead, in virtual ad hoc teams, the concept of Swift Trust replaces the elaborate and timeconsuming establishing of psychological safety. Swift Trust has been initially identified in ad hoc or temporary teams addressing a shared task with a limited life span, such as film crews, theatre groups, or cockpit crews, bringing together experts with diverse backgrounds and abilities and with only a small 


\section{Brazilian

chance of working together in the future (ADAMS et al., 2007, p. 3). Ad hoc teams like that have little or no time and resources to spare to develop mutual trust and relationships.

Swift Trust is based on categorical social structures, basically importing trust from other familiar settings (DAIM et al., 2012, p. 206). Adams describes category-based trust as the identification and categorization of an individual to belong to a certain group. Perceived specific beliefs, expectations, and feelings about that group (such as physicians) result in a judgment about the individuals' trustworthiness (ADAMS et al., 2007, p. 1). This category-based trust enables team members to stay focused on the task, not worrying about the other team-members actions or behavior (ADAMS et al., 2007, p. 4).

Team leaders (or facilitators) can help establish Swift Trust by performing positively voiced introductions and defining the team member's roles clearly, as well as their individual importance to the teams shared efforts (ADAMS et al., 2007, p. 4; DAIM et al., 2012, p. 206).

\section{CREATIVITY}

Creativity has become an essential skill for organizations to be able to adapt to ever-faster innovation cycles and shorter product life spans, while higher levels of competition on a global market and clients demand a maximum of flexibility (VREEDE et al., 2017, p. 20). Amabile defines creativity as "the production of a novel and appropriate response, product, or solution to an open-ended task" (AMABILE, 1996, p. 38, 2012, p. 134) which has been in essence widely used since then (BEYERLEIN et al., 2018, p. 197; VREEDE et al., 2017, p. 21). Amabile further specifies that the outcome has to be new instead of merely different. Based on a heuristic (open-ended) task rather than being purely algorithmic, the result must be "valuable, correct, feasible, or somehow fitting to a particular goal" (AMABILE, 2012, p. 134).

The implementation and realization of a novel idea transforms it into an innovation. Creativity is not just imagination, it always includes the generation of value (PASTOORS, 2018, p. 81). In this context creativity is the precondition of innovation (BECKER, 2018, p. 83). Vreede et al. state: elementary to innovation is "the integration of existing knowledge and ideas into an innovative business model" (VREEDE et al., 2017, p. 20).

The creative process is agreed upon to consist of various stages, including Problem Clarification, Ideation, Comparison and Selection, and Implementation (GESCHKA, 2006, p. 220; NEMIRO, 2004, p. 10; CHAMAKIOTIS et al., 2010, p. 1038). The focus of this work is on the Ideation Phase, considering preconditions and tools relevant for fostering collaborative creativity. 


\section{Brazilian

\subsection{CREATIVITY IN THEORY}

Creativity is in general structured on three different levels: the individual level, the collective (team) creativity, and organizational creativity (GABRIEL et al., 2016, p. 3).

Individual creativity focuses on the abilities and skills of the individual: domain-relevant skills (e.g. special knowledge about the domain or technical expertise), creativity-relevant skills (cognitive and working style, as well as the ability to explore new cognitive pathways and generate novel ideas) and task motivation (motivational aspects that guide an individual's approach to a certain task) (AMABILE, 1996, p. 84, 119; GABRIEL et al., 2016, p. 3).

Collective creativity focuses on how individuals and their creativity interact within a team. This combination of individual contributions leads to more substantial, more creative ideas (VREEDE et al., 2017, p. 21). Considering Cszikszentmihalyis argument, that creativity does not happen in isolation but through interaction (CHAMAKIOTIS et al., 2010, p. 1036) - collective (team) creativity can produce both novel and unique ideas at a high ratio (GABRIEL et al., 2016, p. 3). But, at the same time, it is also the level with the greatest potential for loss of creative efficacy due to social influences, such as production blocking, evaluation apprehension, and free-riding (GABRIEL et al., 2016, p. 4).

Organizational creativity includes the surrounding processes and environments established by the organization or social structure, as well as the culture of the organization and its mindset (GABRIEL et al., 2016, p. 4).

\subsection{INHIBITORS IN COLLECTIVE CREATIVITY}

Besides dominance (or power dynamics) three central inhibiting aspects of the collective creativity stand out: evaluation apprehension, the lack of shared understanding and production blocking (AMABILE, 2012, p. 136; CHAMAKIOTIS, 2011, p. 4, 2014, p. 74; CSIKSZENTMIHALYI, 2016, pp. 169; GABRIEL et al., 2016, p. 3; OCKER, 2007, p. 41; PAULUS; COSKUN, 2020, p. 223).

An approach to eliminating power dynamics and evaluation apprehension in a team could be anonymity. Research and results in this aspect are currently scarce, providing only data with mixed results. Anonymity eliminates status differences, but apparently, it fosters social loafing. Being anonymous in a group seemingly reduces the individuals feeling of responsibility to contribute, and they might be more susceptible to freeriding (PAULUS et al., 2012, p. 338). The aspect of anonymity as potentially amiliorating effect on power dynamics is part of the greater research project, but will not be discussed in depth in this article. 


\section{Brazilian \\ Creative Industries}

Evaluation apprehension is the fear of rejection and negative reactions by the other team members, to more radical or unique ideas. This reflects in the tendency of creative sessions to be limited in the range of ideas, or for team members to converge on more similar categories of ideas (PAULUS et al., 2012, p. 332).

The lack of shared understanding solidifies in the absence of core requirements for the creative team, which are goal clarity, role clarity, and a sense of trust, as well as the potential corrective, namely Shared Mental Models (NEMIRO, 2004, p. 49; VREEDE et al., 2017, p. 23).

Production blocking is primarily known from co-located ideation, referring to how participants must take turns to share ideas since only one person at a time can speak up. This impedes the flow of ideation, inhibiting spontaneous reactions to contributions of others. In that way, valuable ideas - both original and inspired by the ideas of the other participants - can get lost. The critical factor in ideation is the opportunity for individuals to express their ideas as they occur as research has shown (PAULUS et al., 2012, p. 332; PAULUS; COSKUN, 2020, p. 222). It is also established by research, that production losses are less apparent in digital ideation sessions. Information and communication technology (ICT) allows for simultaneous work on the topic, as well as the option to seek out inspiration by the ideas of the other team members, at the individual own pace (PAULUS et al., 2012, p. 243).

\section{METHODOLOGY}

\section{A. SELECTION OF CREATIVITY TECHNIQUES}

Creativity Techniques (CT) in general are tools to "awaken and strengthen the creative potential of individuals" (LEOPOLDINO et al., 2016, p. 95). Using CT in virtual teams, three aspects need to be considered for the selection of a technique: (1) the effectiveness of the method for finding both innovative and relevant solutions, $(2)$ the technological prerequisites (including tools available as well as experience and knowledge of the team members applying them), and (3) the level of interaction required for the CT (TORRES-CORONAS; GASCO-HERNANDEZ, 2008, p. 3).

In literature, a plethora of approaches to categorizing and differentiating individual CT exists: either based on the general approach to the method, the type of thinking required (divergent/convergent), or numerous other factors (Figure 1) (GAUBINGER et al., 2015, p. 122; GESCHKA, 2006, p. 226, p. 234; LEOPOLDINO et al., 2016, p. 98; NEMIRO, 2008, p. 525). 


\section{Brazilian Creative Industries}

\begin{tabular}{|c|c|c|c|c|c|c|c|c|c|}
\hline \begin{tabular}{|c|}
$\begin{array}{c}\text { Creativity } \\
\text { Techniques }\end{array}$ \\
Characteristics \\
\end{tabular} & $\begin{array}{l}\text { Storyboarding } \\
\text { Vance (1982) }\end{array}$ & \begin{tabular}{c|} 
Synetics \\
Gordon (1961)
\end{tabular} & $\begin{array}{c}\text { Morphological } \\
\text { Analysis } \\
\text { Zwicky (1969) }\end{array}$ & $\begin{array}{c}\text { TRIZ } \\
\text { Altshuller } \\
\text { (1984) }\end{array}$ & $\begin{array}{c}\text { Brainwriting } \\
\text { Rohrbach } \\
\text { (1969) }\end{array}$ & \begin{tabular}{|c|} 
Six Thinking \\
Hats \\
De Bono (1970) \\
\end{tabular} & \begin{tabular}{|c|} 
Lateral \\
Thinking \\
De Bono $(1970)$
\end{tabular} & $\begin{array}{c}\text { Force Field } \\
\text { Analysis } \\
\text { Lewin (1947) }\end{array}$ & $\begin{array}{l}\text { Brainstorming } \\
\text { Osborn (1963) }\end{array}$ \\
\hline Application & Collective & Collective & $\begin{array}{c}\text { Individual and } \\
\text { Collective }\end{array}$ & $\begin{array}{l}\text { Individual and } \\
\text { Collective }\end{array}$ & Collective & $\begin{array}{l}\text { Individual and } \\
\text { Collective }\end{array}$ & Collective & $\begin{array}{l}\text { Individual and } \\
\text { Collective }\end{array}$ & $\begin{array}{c}\text { Individual and } \\
\text { Collective }\end{array}$ \\
\hline $\begin{array}{c}\text { Type of } \\
\text { Thinking }\end{array}$ & $\begin{array}{l}\text { Divergent and } \\
\text { Convergent }\end{array}$ & $\begin{array}{c}\text { Divergent and } \\
\text { Convergent }\end{array}$ & Convergent & Convergent & $\begin{array}{c}\text { Divergent and } \\
\text { Convergent }\end{array}$ & $\begin{array}{l}\text { Divergent and } \\
\text { Convergent }\end{array}$ & Divergent & Convergent & $\begin{array}{c}\text { Divergent and } \\
\text { Convergent }\end{array}$ \\
\hline $\begin{array}{c}\text { Average } \\
\text { Session Time }\end{array}$ & $30-45 \mathrm{~min}$. & $\begin{array}{c}\text { Until task } \\
\text { completion }\end{array}$ & $\begin{array}{c}\text { Until task } \\
\text { completion }\end{array}$ & $\begin{array}{c}\text { Until task } \\
\text { completion }\end{array}$ & $30 \mathrm{~min}$. & $60 \mathrm{~min}$. & $\begin{array}{c}\text { Until task } \\
\text { completion }\end{array}$ & $\begin{array}{l}\text { Until task } \\
\text { completion }\end{array}$ & $10-60 \mathrm{~min}$. \\
\hline $\begin{array}{c}\text { Operating } \\
\text { Criteria }\end{array}$ & $\begin{array}{l}\text { Exploration and } \\
\text { validation }\end{array}$ & $\begin{array}{c}\text { Exploration, } \\
\text { combination and } \\
\text { validation }\end{array}$ & $\begin{array}{l}\text { Exploration and } \\
\text { transformation }\end{array}$ & $\begin{array}{c}\text { Exploration and } \\
\text { validation }\end{array}$ & Exploration & $\begin{array}{l}\text { Exploration, } \\
\text { combination, } \\
\text { transformation } \\
\text { and validation }\end{array}$ & $\begin{array}{c}\text { Combination and } \\
\text { transformation }\end{array}$ & $\begin{array}{l}\text { Exploration and } \\
\text { transformation }\end{array}$ & $\begin{array}{l}\text { Exploration and } \\
\text { combination }\end{array}$ \\
\hline $\begin{array}{c}\text { Material } \\
\text { Resources }\end{array}$ & Cards & No material & No material & No material & Blank sheets & 6 colorful hats & No material & Blackboard & No material \\
\hline Approach & $\begin{array}{l}\text { Analytical } \\
\text { Technique }\end{array}$ & $\begin{array}{l}\text { Associative } \\
\text { Technique }\end{array}$ & $\begin{array}{l}\text { Analytical } \\
\text { Technique }\end{array}$ & $\begin{array}{l}\text { Analytical } \\
\text { Technique }\end{array}$ & $\begin{array}{l}\text { Associative } \\
\text { Technique }\end{array}$ & $\begin{array}{l}\text { Analytical } \\
\text { Technique }\end{array}$ & $\begin{array}{c}\text { Provocation } \\
\text { Technique }\end{array}$ & $\begin{array}{l}\text { Analytical } \\
\text { Technique }\end{array}$ & $\begin{array}{l}\text { Provocation } \\
\text { Technique }\end{array}$ \\
\hline
\end{tabular}

Figure 1: Analysis of creativity techniques (LEOPOLDINO et al., 2016, p. 98)

A clear and selective distinction is not feasible, since methods exist in numerous variations and often contain elements of several categories (GAUBINGER et al., 2015, p. 121).

Based on the different categorizations of CT identified in current literature, it is the intent of this work to identify and choose CT based on concepts and approaches as diverse as possible for the experiment. Besides, the chosen methods have to be applicable in a virtual ideation session using technological means. Based on the literature research of Leopoldino (Figure 1), illustrating the most cited CT in research up to 2015, and taking into consideration the various variables for categorization, the following three CT are selected for evaluation: Brainwriting "6-5-3-Method", Reverse Brainstorming, and Walt-Disney-Method(Table 1).

Table 1: Three CT selected for the experiment

\begin{tabular}{lll}
\hline $\begin{array}{l}\text { Creativity } \\
\text { Technique (CT) }\end{array}$ & Criteria for selection & Procedure/main principle \\
\hline $\begin{array}{l}\text { 6-5-3 Method } \\
\text { (Brainwriting) }\end{array}$ & $\begin{array}{l}\text { Preserving Paradigm } \\
\text { Technique }\end{array}$ & Generation of ideas without criticism \\
\cline { 2 - 3 } & Associative Technique & Recombination of elements to generate new ideas \\
\cline { 2 - 3 } & Linear/analytical & $\begin{array}{l}\text { Logical patterns of thinking } \\
\text { Applying linear pattern/sequence of steps }\end{array}$ \\
\cline { 2 - 3 } & Divergent/convergent & $\begin{array}{l}\text { Convergent: reorganization/integration of ideas } \\
\text { thinking }\end{array}$ \\
\cline { 2 - 3 } & Divergent: using unusual approaches and categories of memory \\
\cline { 2 - 3 } & Used for: exploration & \\
\hline & & \\
\hline
\end{tabular}




\section{Brazilian Creative Industries}

\begin{tabular}{|c|c|c|}
\hline \multirow[t]{9}{*}{$\begin{array}{l}\text { Reverse } \\
\text { Brainstorming }\end{array}$} & $\begin{array}{l}\text { Stretching Paradigm } \\
\text { Technique }\end{array}$ & $\begin{array}{l}\text { Participants generate ideas using objects/pictures } \\
\text { unrelated to the problem }\end{array}$ \\
\hline & Provocative & Relying on symbol/picture to jump-start solutions \\
\hline & Technique & + \\
\hline & & Recombination of elements + seeking to break with preconceived \\
\hline & Associative Technique & thought structures \\
\hline & Linear/analytical & Logical patterns of thinking \\
\hline & & Applying linear pattern/sequence of steps \\
\hline & Divergent/convergent & Convergent: reorganization/integration of ideas \\
\hline & thinking & Divergent: using unusual approaches and categories of memory \\
\hline & \multicolumn{2}{|c|}{ Used for: exploration and combination } \\
\hline $\begin{array}{l}\text { Creativity } \\
\text { Technique (CT) }\end{array}$ & Criteria for selection & Procedure/main principle \\
\hline \multirow[t]{8}{*}{$\begin{array}{l}\text { Walt-Disney- } \\
\text { Method }\end{array}$} & $\begin{array}{l}\text { Breaking Paradigm } \\
\text { Technique }\end{array}$ & $\begin{array}{l}\text { Participants look at the perfect future, examine and evaluate } \\
\text { fantasy statements, look at how ideas could be achieved; }\end{array}$ \\
\hline & Imagination technique & Guided imaginary journey; imagination of perfect future \\
\hline & + & + \\
\hline & $\begin{array}{l}\text { Technique of } \\
\text { structured association }\end{array}$ & $\begin{array}{l}\text { Structured/assisted recombination of elements to generate new } \\
\text { ideas }\end{array}$ \\
\hline & Intuitive & $\begin{array}{l}\text { Relying on symbol/picture to jump-start solutions; encourages } \\
\text { sudden leaps of logic }\end{array}$ \\
\hline & Divergent/convergent & Convergent: reorganization/integration of ideas \\
\hline & thinking & Divergent: using unusual approaches and categories of memory \\
\hline & \multicolumn{2}{|c|}{ Used for: Exploration/combination/transformation/validation } \\
\hline
\end{tabular}

Table 1: Criteria for selection of CT (GAUBINGER et al., 2015, p. 122; GESCHKA, 2006, p. 226, p. 234; LEOPOLDINO et al., 2016, p. 98; NEMIRO, 2008, p. 525).

\subsection{RESEARCH APPROACH}

In this experimental research, an exploratory design was applied. Despite an abundance of literature focusing on singular aspects of creativity from a variety of angles and the usability and effects of CT in co-located teams, to the authors' knowledge, no extensive practical research was conducted so far to test the feasibility and acceptance of various CT in virtual surroundings.

This research aims to develop a well-grounded impression of the general feasibility and acceptance of creativity techniques in virtual ideation. Selected CT representing various approaches and ideation methods were tested to evaluate the factual applicability from both the technical as well as the participants' view. 


\section{Brazilian \\ Creative Industries}

Following the experiment, the participants' experiences were collected through an additional anonymous online survey.

\subsection{SAMPLE - METHODS/CRITERIA}

Essentially the sample for this research is a convenience sample, consisting of individuals of the author's network, namely students and employees of IST - University of Applied Sciences Düsseldorf/ Germany, social media, and a respectable amount of employees of various departments of SAP SE in Germany. The aim was for maximum randomization, though limited by the factor language since a distinction between German and English native speakers was made resulting in separate German- and English-language experimental sessions.

A total of 43 potential participants registered for the experiment. Eight test groups were built, ranging from as few as three participants up to the target size of six participants. The finally achieved sample size was 37 in total. Two experiments were conducted with the group of six, another two with a group size of five. To gather enough data material, two experiments with only three participants each had to be conducted twice, relutling in a total of eight experiments. 12 participants tested CT1 "6-5-3 Brainwriting", 10 participants used CT2 "Reverse Brainwriting", and 15 participants tested CT3 "Walt-Disney-Method".

\subsection{RESEARCH DESIGN}

The design used in this research is a 1 $\times 3$ factorial design. The levels (attributes) of the factor "Creativity technique" are the three CT selected (Table 1), tested with eight ad hoc test groups. The dependent variable is therefore the individual and subjective perception and acceptance of the CT tested through the participants of the test.

The data collected from the experiment consists of three aspects: the number of (unique) creative ideas from the experiment itself, as well as the overall rating of the CT and general acceptance of the creative process in the virtual setting.

\subsection{EXPERIMENT - THE IDEATION SESSION}

The objective of the experiment was to test selected CT using a digital whiteboard (www.mural.co, 2020), working on a set creative task. The focus in the first place was not to get usable and valuable results to the predefined topic, but rather to explore the usability of CT and the interaction of the participants to accomplish solving the question at hand. All three CT had a set time frame of 15 minutes for the ideation part itself. In total, the sessions took place during November and December 2020 and lasted about 25-35 minutes each. 


\section{Brazilian \\ Creative Industries}

In advance, all participants received an invitation link to a Zoom conference as a starting point of all experimental sessions. To accommodate English native-speaking participants, both settings were carried out in English as well, though the majority of the experiment was conducted in German. The creative task given to the participants was to generate ideas what will Learning be like in 10 years time, i.e. in the year $2030 ?$

\subsection{SET-UP OF CT}

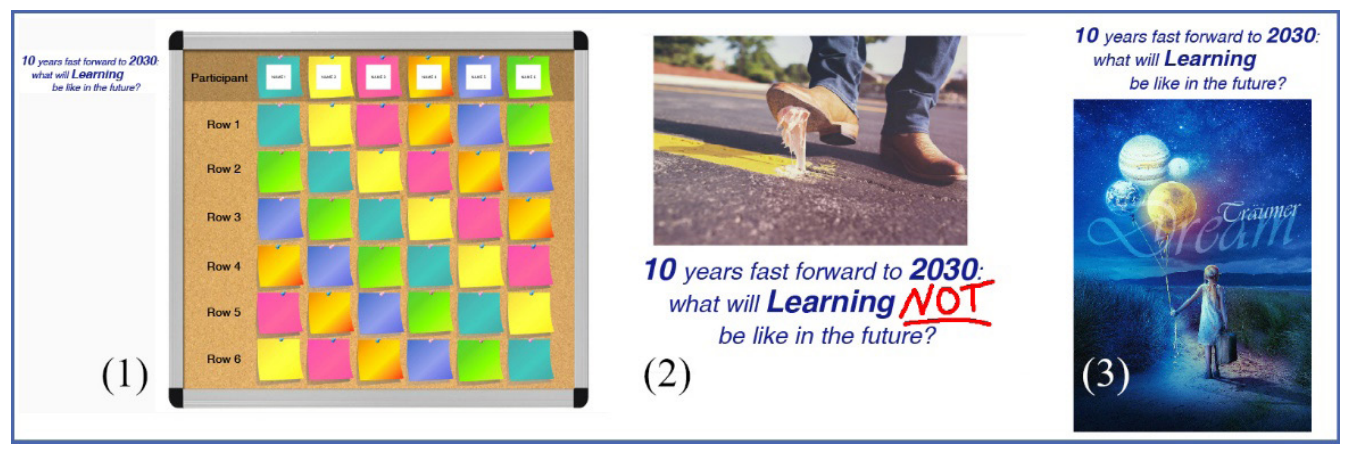

Figure 2: Set-up of Mural-boards at the beginning of the session

6-5-3-Method (1): Six participants per session started in the first row on his/her sticky note of chosen color with three original ideas each. The time limit was 2:30 minutes per row. After the allotted time elapsed, the participants moved down one line and one sticky note to the right (according to their dedicated color). This time, they had to elaborate on the ideas in the row directly above. The focus from rows 2-6 was to further develop, modify, explore, or enhance those ideas.

Reverse Brainstorming (2): The aim was to collect as many ideas as possible. The focus was on how things should NOT be. Listing all aspects that make the prospect a failure, resulting in a complete breakdown, imagine all the worst things to happen. The time limit here was set to 15 minutes.

Walt-Disney-Method (3): The technique is divided into three parts of 5 minutes ideation each. The starting point of view is the "Dreamer", where the participants are asked to imagine their ideal future on blue sticky notes - however abstract or strange the ideas may be. In the second step, they were asked to use yellow sticky notes to elaborate on the realistic implementation of their so far collected "ideal fantasy ideas". In the final part, pink sticky notes were used to note down all the doubts, hindrances, and obstacles. 


\section{Brazilian Creative Industries}

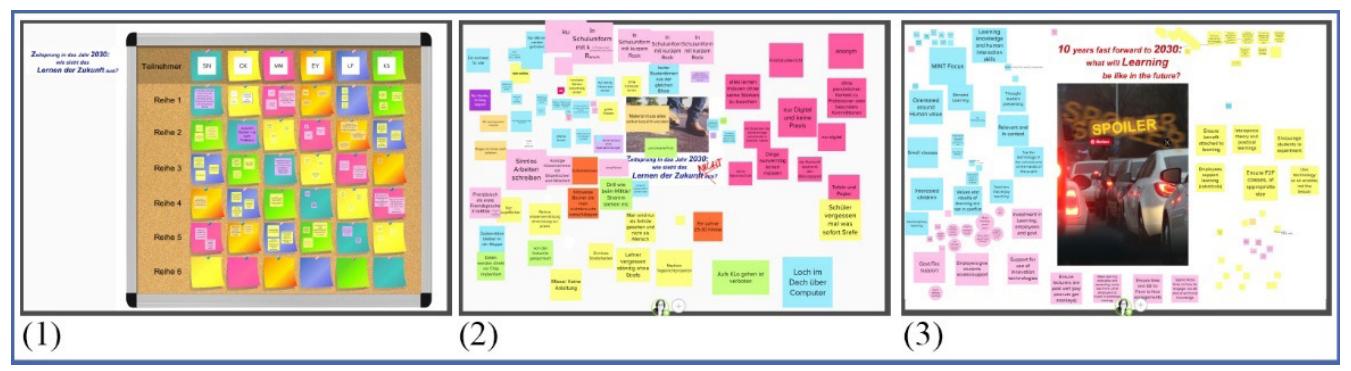

Figure 3: Mural-boards at the end of the session (examples)

\subsection{ANONYMOUS ONLINE SURVEY}

The survey was sent out immediately after the respective ideation session. The questions were focused on the key aspects of task and goal clarity, the general acceptance of CT applied and the tool (whiteboard) used. Additional questions explored the factors "production blocking" and "idea-building" deemed to be of special significance in VT. To categorize and cluster participants, questions in the survey were added to address significant demographic factors including previous experiences with (virtual) teamwork and the use of CT.

\subsection{COLLECTED DATA - PROCESSING AND ANALYSIS}

During the experiment and the ensuing online-survey, two sets of primary data were collected. First, the total number of ideas, as well as the total number of unique creative ideas per ideation session were set into relation to the number of participants per CT to obtain the average idea/participant-ratio, respectively unique idea/participant-ratio.

With the anonymous survey, a mix of quantitative and qualitative data was collected. For the majority of questions, a 6 -point Likert-scale was applied to supply ordinally scaled data for univariate analysis. All quantitative data were processed using Excel. All qualitative data from the open-ended questions of the survey were imported, encoded, and processed with MAXQDA.

\section{RESULTS AND ANALYSIS}

\subsection{PARTICIPANTS - DEMOGRAPHIC DATA}

As the sample used for this research was a convenience sample, essentially consisting of volunteers from the author's network, the basic demographic data is used to put the results into perspective (Figure 4): 


\section{Brazilian Creative Industries}

Participants according to age-groups:

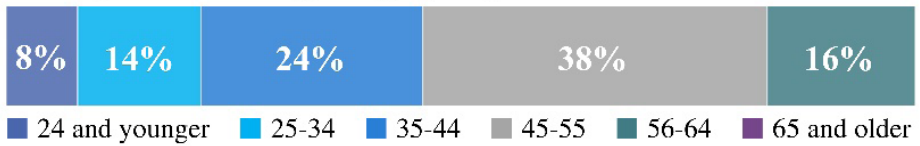

Use of Internet on a daily base:

\begin{tabular}{ll|l} 
& $38 \%$ \\
private & $62 \%$ \\
\hline
\end{tabular}

\begin{tabular}{|r|r|r|}
\hline $60 \%$ & $27 \%$ & $8 \% 5 \%$ \\
\hline
\end{tabular}

work-related

\begin{tabular}{|l|l|l|l|l|}
\hline $24 \%$ & $24 \%$ & $30 \%$ & $14 \%$ & $8 \%$
\end{tabular}

educational/school/university

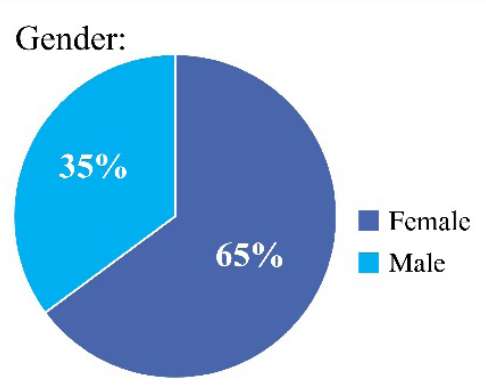

constantly several times a day moderatly rarely not at all

Figure 4: Participants ( $=37)$ - demographic data

\subsection{RESULTS FROM IDEATION SESSIONS}

In the first step, the total number of ideas per CT used was identified (Table 2).

\begin{tabular}{lll}
\hline $\begin{array}{l}\text { 6-5-3 Brainwriting: } \\
\text { total no. of ideas }\end{array}$ & $\begin{array}{l}\text { Reverse Brainstorming: } \\
\text { total no. of ideas }\end{array}$ & $\begin{array}{l}\text { Walt-Disney-Method: } \\
\text { total no. of ideas }\end{array}$ \\
\hline 143 ideas & 128 ideas & 293 ideas \\
\hline
\end{tabular}

Table 2: Total number of ideas

In a second step, ideas were clustered based on connecting categories (for example "training of teachers", "aspects of flexible/blended learning", "needs for governmental changes", "technical requirements") to identify unique ideas (Table 3).

\begin{tabular}{lll}
\hline $\begin{array}{l}\text { 6-5-3 Brainwriting: } \\
\text { total no. of unique ideas }\end{array}$ & $\begin{array}{l}\text { Reverse Brainstorming: } \\
\text { total no. of unique ideas }\end{array}$ & $\begin{array}{l}\text { Walt-Disney-Method: } \\
\text { total no. of unique ideas }\end{array}$ \\
\hline 73 unique ideas & 84 unique ideas & 123 unique ideas \\
\hline
\end{tabular}

\section{Table 3: Total number of unique ideas}

This results in the following ratios of the total amount of ideas/participants (Ps)(Table 4) as well as the total amount of unique ideas/participant in each CT-category (Table 5):

\begin{tabular}{lll}
\hline 6-5-3 Brainwriting (12 Ps) & Reverse Brainstorming (10 Ps) & Walt-Disney-Method (15 Ps) \\
\hline$\varnothing 11.92$ ideas & $\varnothing 12.80$ ideas & $\emptyset 19.53$ ideas \\
\hline
\end{tabular}

Table 4: Ratio of the total amount of ideas/participant 


\section{Brazilian Creative Industries}

\begin{tabular}{lll}
\hline 6-5-3 Brainwriting (12 Ps) & Reverse Brainstorming (10 Ps) & Walt-Disney-Method (15 Ps) \\
\hline$\varnothing 6.08$ unique ideas & $\varnothing 8.40$ unique ideas & $\varnothing 8.20$ unique ideas \\
\hline & Table 5: Ratio of the total amount of unique ideas/participant
\end{tabular}

Table 5: Ratio of the total amount of unique ideas/participant

Hypothesis 1a is neither confirmed nor falsified: apparently CT with different approaches lead to different numbers of unique ideas (Table $3+$ Table 5 ). The results bring forth the assumption, that the more intuitive or imaginative a technique is, the more inviting to break existing paradigms and think outside the box, the more unique ideas are possible. The data collected is too insubstantial though, to confirm this hypothesis. Further research on this topic is suggested.

\subsection{ACCEPTANCE OF CT}

Two-thirds of the participants had made experiences using CT to generate ideas before the experiment. 57\% had already participated in virtual creative sessions before. Then again, the CT used in the experiment were predominantly new to the participants (Figure 5).

\begin{tabular}{|c|c|c|}
\hline $\begin{array}{l}\text { Question 5: The creativity } \\
\text { technique used was previously } \\
\text { unknown to me }\end{array}$ & $\begin{array}{l}\text { Question 6: Have you ever used } \\
\text { creativity techniques before to } \\
\text { generate ideas? }\end{array}$ & $\begin{array}{l}\text { Question 8: Did you have any } \\
\text { experiences with digital/virtual } \\
\text { creative sessions before this } \\
\text { experiment? }\end{array}$ \\
\hline $\begin{array}{l}\text { yes } \\
\text { no }\end{array}$ & $\begin{array}{l}=\text { yes } \\
\text { no }\end{array}$ & $\begin{array}{l}\text { yes } \\
\text { no }\end{array}$ \\
\hline
\end{tabular}

Figure 5: Survey results $(\mathrm{n}=37)$ - experience with $\mathrm{CT}$

Comparing the general results on the acceptance of the CT within the survey, participants widely agree on the CT being comprehensibly explained in the introduction, the CT being easy to apply, and inspiring new ideas. Participants also considered the creative session to having been fun and being successful.

This is essentially mirrored in the results of the respective CT (Figure 6): 


\section{Brazilian Creative Industries}

Question 4.1: I was able to easily apply the CT

\begin{tabular}{|c|c|c|c|c|}
\hline \multicolumn{2}{|c|}{$67 \%$} & $17 \%$ & $8 \%$ & $8 \%$ \\
\hline $\begin{array}{c}40 \% \\
\text { Reverse_Brainstorming }\end{array}$ & & & & \\
\hline $\begin{array}{l}20 \% \\
\text { Walt-Disney-Method }\end{array}$ & $47 \%$ & $20 \%$ & & $3 \%$ \\
\hline
\end{tabular}

Question 11.1: The creative session was fun

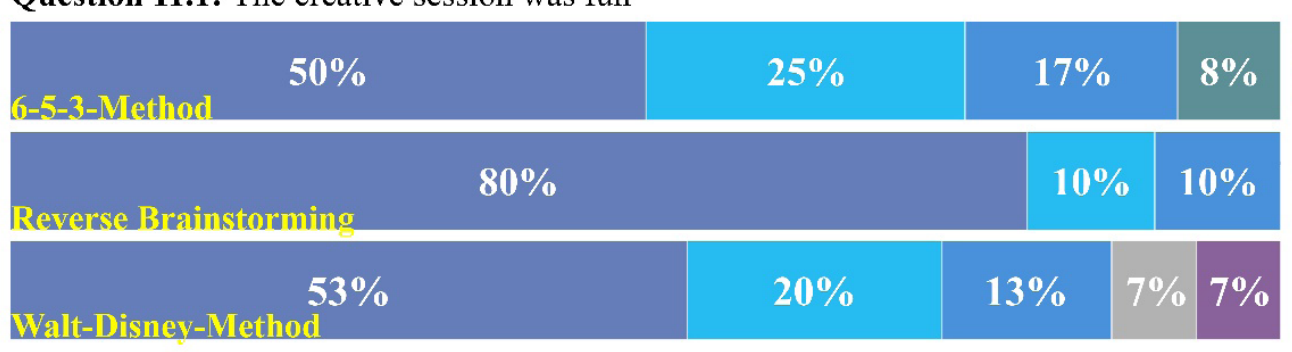

strongly agree agree a somewhat agree - somewhat disagree disagrec strongly disagree

Question 11.5: The creative session was successful

\begin{tabular}{|c|c|c|c|c|}
\hline $\begin{array}{c}17 \% \\
6-5-3-M e t h o d\end{array}$ & $3 \%$ & \multicolumn{2}{|c|}{$25 \%$} & $\begin{array}{l}\text { agree } \\
\text { somewhat agree }\end{array}$ \\
\hline $\begin{array}{c}30 \% \\
\text { Reverse_Brainstorming }\end{array}$ & \multicolumn{2}{|c|}{$60 \%$} & $10 \%$ & $\begin{array}{l}\text { n disagree } \\
\text { strongly disagree }\end{array}$ \\
\hline $\begin{array}{c}40 \% \\
\text { Malt_Disnev-Method }\end{array}$ & $20 \%$ & $27 \%$ & $13 \%$ & \\
\hline
\end{tabular}

Figure 6: Survey results $(n=37)$ - acceptance of respective CT in comparison

In the subsequent survey, open-ended questions were dedicated to collect insight on the acceptance of the CT, asking for previous experiences (and if they were good or bad) with CT in general and especially virtual ideation. One question explicitly asked for feedback on the respective CT (Table 6). 


\section{Brazilian \\ Creative Industries}

\begin{tabular}{|c|c|c|}
\hline CT & Positive & Negative \\
\hline 6-5-3-Method & $\begin{array}{l}\text { "Lots of impressions on a particular topic" } \\
\text { "The whole structure - that is, that you build on the idea of the } \\
\text { predecessor." } \\
\text { "Time-boxed, team-oriented, open, transparent, based on/using an } \\
\text { intuitive collaboration tool" } \\
\text { "The visualization of the WB" } \\
\text { "The time management" } \\
\text { "To be able to see the ideas of the others as they emerge" }\end{array}$ & $\begin{array}{l}\text { "There was no personal } \\
\text { exchange or discussions" } \\
\text { "The time was very short to } \\
\text { think about the statement of } \\
\text { the predecessor" } \\
\text { "The connection to the } \\
\text { row above was not always } \\
\text { recognizable" }\end{array}$ \\
\hline $\begin{array}{l}\text { Reverse } \\
\text { Brainstorming }\end{array}$ & $\begin{array}{l}\text { "Low inhibition threshold, easy to use technique, fun factor" } \\
\text { "The inverse stimulated the absurd" } \\
\text { "(...) due to the possibility of complete negative exaggeration, one rather } \\
\text { thinks "outside of the usual limits".'. } \\
\text { "Everybody was able to participate and see the others' ideas at the same } \\
\text { time" } \\
\text { "the reverse approach (...) another helpful way to shed light on a topic and } \\
\text { releases further ideas that you might not otherwise have thought of" }\end{array}$ & $\begin{array}{l}\text { "Little real interaction" } \\
\text { "There was no contact with } \\
\text { the others, on the other hand, } \\
\text { it made you less distracted" }\end{array}$ \\
\hline $\begin{array}{l}\text { Walt- } \\
\text { Disney- } \\
\text { Method }\end{array}$ & $\begin{array}{l}\text { "That you can see directly what the others were writing which creates new } \\
\text { ideas" } \\
\text { "all participants can "talk" at once, make their contributions without } \\
\text { bothering each other" } \\
\text { "different angles of view; good structure; free (associative) thinking" } \\
\text { "I think that for good results it is above all crucial to let the "dreamer" get to } \\
\text { work first; I found the technique very exciting" } \\
\text { "The Dreamer perspective" } \\
\text { "I think the instruction to write down all the possible ideas, however wild, is } \\
\text { useful in enhancing creativity by temporarily silencing the critical thoughts, } \\
\text { and then giving those critical thoughts a separate space means it is easier } \\
\text { to silence them at the start!" } \\
\text { "The different levels make it very easy to bring new ideas to your head." } \\
\text { "well-chosen pictures, assignment of colors (= structure)" }\end{array}$ & $\begin{array}{l}\text { "The personal exchange } \\
\text { is unfortunately missing, } \\
\text { exciting discussions, } \\
\text { eye contact, and facial } \\
\text { expressions, gestures, fun, } \\
\text { and laughter" }\end{array}$ \\
\hline
\end{tabular}

Table 6: Survey results ( $\mathrm{n}=37$ ) - exemplary quotes regarding positive/negative experiences with CT during the experiment (individual answers from open-ended question, translations by authors)

Asked about previously made experiences with ideation sessions, participants reported of others having difficulties to get involved, considering CT as "child's play". Another participant recalled that "it often is difficult in the beginning. From the moment, the people dare to participate, it often works pretty well [transl. by authors]".

The aspect of timeboxing was seen as very controversial. Though many of the participants mentioned that they do not like time pressure and considered the time allocated for the ideation session as too short, others considered timeboxing as conducive. One participant mused: "Actually I don't like time pressure, but 


\section{Brazilian Creative Industries}

with creativity techniques, it feels more like a spur to action [transl. by authors]". And another participant who felt distinctly rushed, admitted that "...despite the rush or especially because of that, I had a feeling of really having achieved something [transl. by authors]".

Comparing the results and quotes on the acceptance of CT in virtual ideation during this experiment, Hypothesis $\mathbf{1 b}$ is only partially confirmed. Though the three CT indeed were differently perceived, it was not possible to pinpoint exactly the discriminating factors, linking them to the characteristic attributes of the CT. Further research needs to be conducted to identify the stimulating effects of certain CT on individual creativity.

\subsection{PRODUCTION BLOCKING}

As a major inhibitor of team creativity, production blocking was evaluated through various questions. In Q20 of the survey, the blocking effects were directly assessed and were at large negated (Figure 7). Thus, Hypothesis $\mathbf{2}$ is therefore considered confirmed: production blocking in virtual team-ideation using a digital whiteboard is not existent.

Question 20.1: I felt like I had to wait for the others all the time

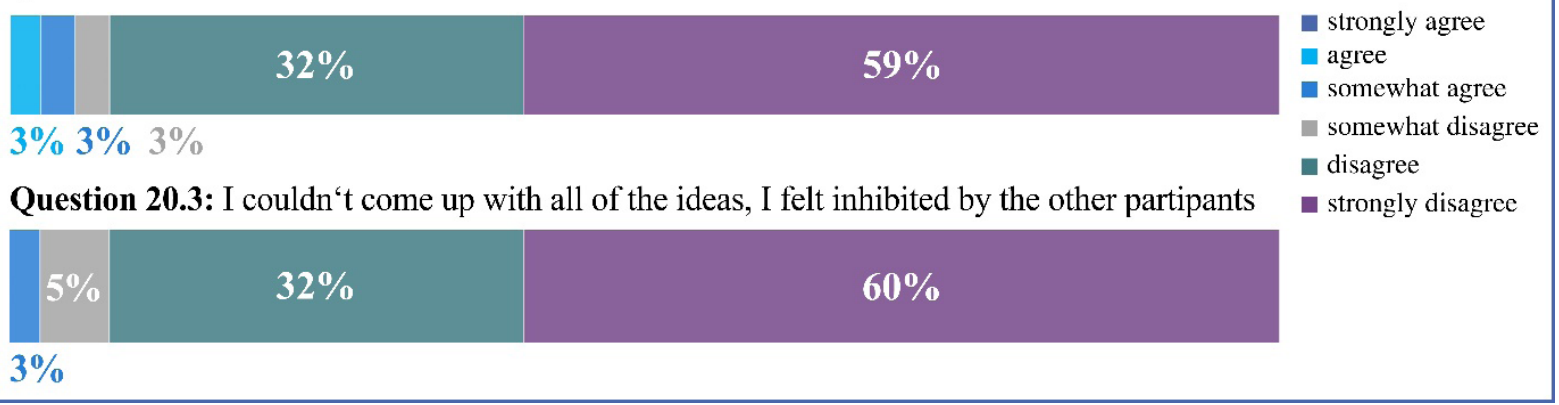

Figure 7: Survey results $(\mathbf{n}=\mathbf{3 7})$ - production blocking

Simultaneous collaboration on the whiteboard was received mainly in a positive way: "Everybody was able to contribute and watch at the same time, that was great [transl. by authors]". "...that I can see what the others are writing and from that new own ideas emerge [transl. by authors]".

\subsection{IDEA BUILDING}

Questions dealing with the aspect of idea building as a central attribute of shared creativity in ideation sessions, yielded mixed results (Figure 8). 


\section{Brazilian Creative Industries}

Question 18.5: I paid attention to the ideas of others and built on them

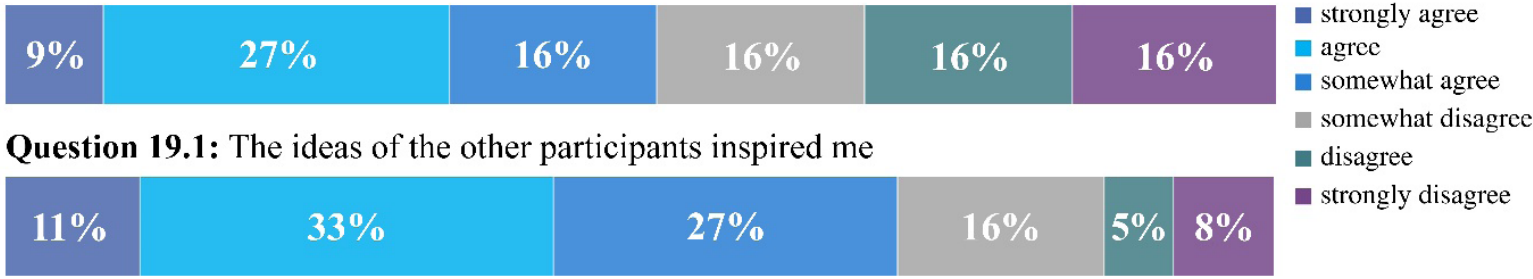

Question 19.3: The ideas of the other participants gave me new ideas myself
$16 \%$
$30 \%$
$22 \%$
$13 \%$
$11 \%$
$8 \%$

\section{Figure 8: Survey results $(n=37)$ - idea building}

Answers in the open-ended text fields of the survey indicated a rather negative view of the aspect of idea-building:

"The simultaneous appearance of the other participants' ideas rather impeded my own creativity. I'd rather have the other's contributions appear after the time's up for the session [transl. by authors]".

"It was difficult to read and build upon the others post-its (...) [transl. by authors]".

"...no real interaction [transl. by authors]".

It was observed by the facilitator during the experiment, that participants lost sight of the topic, as well as each other when using a large zoom-factor and using just a very small part of the board, which might have inhibited the idea-building.

Hypothesis $\mathbf{3}$ is also considered confirmed since the results do allow an assumption that ideabuilding in virtual ad hoc teams seems to be less apparent.

\subsection{ACCEPTANCE OF WHITEBOARD}

The usability and acceptance of the WB (Mural) were assessed being essentially connected to the usability and acceptance of the $\mathrm{CT}$. The survey revealed, that about half of the participants already had experiences with virtual whiteboards, while two-thirds of the participants reported no problems using the WB (Figure 9). 


\section{Brazilian Creative Industries}

Question 13: Have you worked with a virtual whiteboard before?

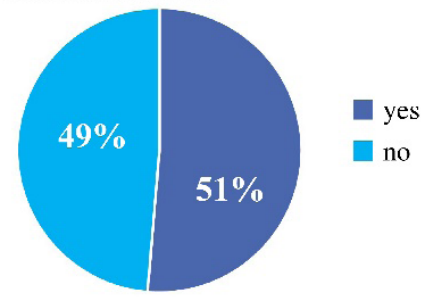

Question 16: Did you have any problems using the whiteboard?

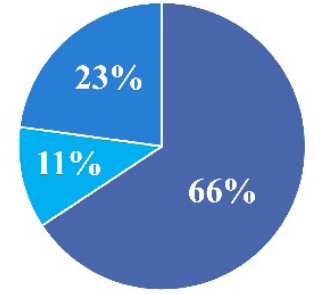

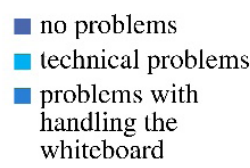

Question 15.1: The whiteboard was well suited for collaboration

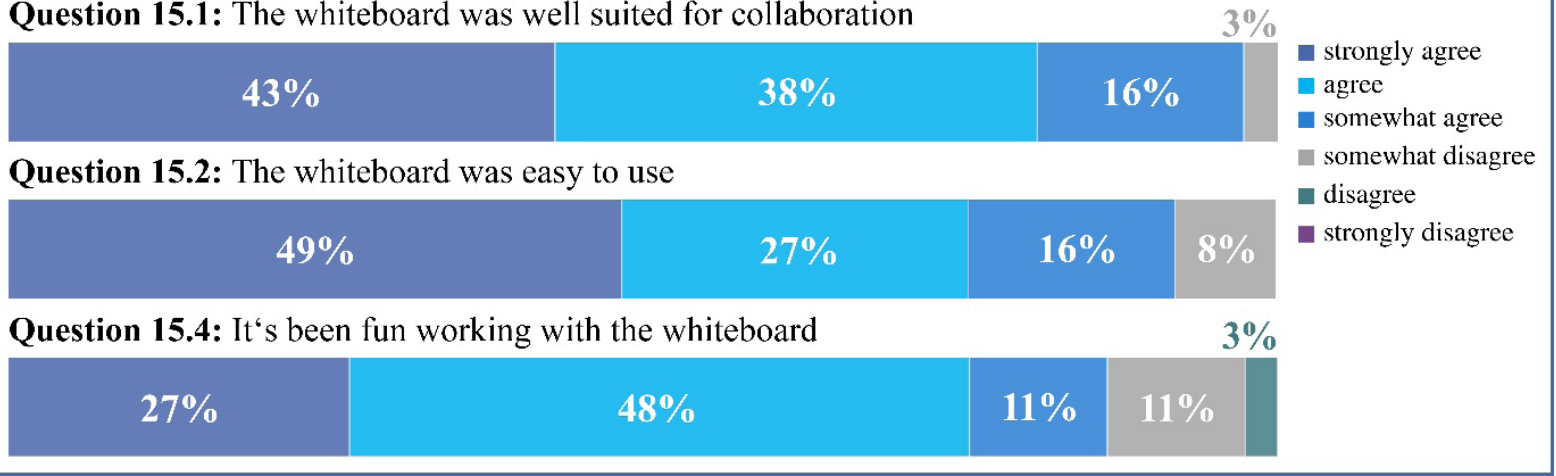

Figure 9: Survey results $(\mathbf{n}=\mathbf{3 7})$ - acceptance of WB

The majority of technical difficulties reported were ascribable to issues outside of Mural, such as lagging internet connection or the reportedly rather awkward handling when using a touchpad instead of a mouse. The gist of the individual statements about the virtual whiteboard were positive though, naming it "intuitive in handling", "interesting" and "easy to use". As a distinct advantage of virtual ideation, the easy documentation of results was considered.

\section{DISCUSSION}

Within the scope of this research, the aim was to select CT based on theoretical research to be later tested and evaluated by ad hoc teams. Building up task connection included distinct instructions on how to use the WB as well as the respective CT. Chang also defined a shared vision as an enabler of effective team collaboration (Chang, 2011, pp. 269). The connecting vision has been to ideate on a distinctly framed given topic using a tool and CT provided. The findings show this was successfully established. 


\section{Brazilian

\subsection{ICT/WHITEBOARD}

Half of the participants already had experience using a virtual WB before. Generally, the WB was well-received, with the majority agreeing on it to be easy to use. Rare criticism voiced rather referred to the set-up in total, being too much at once: handling the WB, using an unknown CT in addition to considering a problem to ideate about. Though a minority agreed that handling the WB was complicated, the consensus was, given a bit of time to practice, that a WB is well suited for collaboration. Easy and intuitive handling of ICT in virtual collaboration does not only assist virtual ideation sessions in yielding fast results but also as Vreede et al. mentioned, productivity improvements of 50\% may be experienced (Vreede et al., 2017, p. 20).

\subsection{CREATIVITY TECHNIQUES}

The overall perception of the three CT tested was positive. The results are very close in comparison though, therefore conclusions are not easy to be made.

Reverse Brainstorming was especially well accepted which resulted in top results in understandability of the $C T$, its ease to apply along its potential to inspire new ideas - in fact making it the top result of all three CT. Having fun during the process of ideation as well as the inverse approach triggering new ways of thinking were mentioned most in the open-ended questions.

Interestingly on average the perception of the Reverse Brainstorming-session being successful and the outcome classified as satisfying ("We collected really good ideas") was somewhat lower than for example the results of the 6-5-3-Method.

The 6-5-3-Method was also very well perceived by one of the teams, by chance being combined of several very structured and analytical thinking participants (as noted in observation of the creative session and evaluating the answers to the open-ended questions). Observing this team, it was noted, that the structured approach of the CT suited the participants. Apparently the more convergent thinking, linear approach resulted in high efficiency with minimal technical and handling issues (both WB and CT). Answers in surveys after this session noted the advantage of iterative over linear ideation, though. This leads to the assumption, that the linear approach, though less wide in looking at categories of ideation, might have an advantage in being used iteratively.

The Walt-Disney-Method lead to ambivalent results: it yielded about double as many ideas in total, as well as the most unique ideas of the experiment. Considering the unique idea/participant-ratio though, however, all three CT are again very close. At first sight - the Walt-Disney-Method appears to be the CT 


\section{Brazilian \\ Creative Industries}

to trigger creativity the most in virtual ad-hoc teams, resulting in a lot of ideas. On closer look, however it did not result in considerably more unique ideas than the other two CT.

Also, the technique itself was perceived ambiguously: apparently, it requires more explaining and probably more time to get used to. Positively considered were the three steps of ideation: a clear distinction between "Dreamer", "Realist" and "Spoiler" - and in doing so enabling a truly creative first step using mainly divergent thinking, with free-flowing ideation, knowing that all doubts and hindrances will be considered in a second and third step.

The findings from the experiment also spotlighted, that the acceptance of a CT is heavily dependent on team composition as one of the defining influential variables on team creativity, as well as the disposition of the members towards creativity. Hence the selection of a CT should be based not only on consideration of the intended outcome but also according to the predominant way of thinking. This entails future research, as well as the consideration of how to develop CT, especially for rationally oriented individuals.

\subsection{PRODUCTION BLOCKING}

As declared in hypothesis $\mathrm{H} 2$, the expected outcome was of no apparent production blocking which is according to Paulus et al. the main advantage, resulting in fewer production losses (Paulus et al., 2012, p. 332, p. 243). This is mainly substantiated by the results, participants expressing they did not feel particularly inhibited by other participants. While observing the ideation sessions, it occurred that due to different zoom-factors on the Mural-board used by the participants, sometimes sticky notes added were really big and encumbered the use of the board for other participants. Also upon nearing the end of the session, when boards tend to get full, this has been noted as a possible limitation.

The 6-5-3-Method on the other hand especially requires building upon each other's ideas. In these sessions, production blocking was experienced more often than in the other two CT.

\subsection{IDEA BUILDING}

As formulated in hypothesis $\mathrm{H} 3$, idea building was indeed less apparent in the experiment. In observation of the ideation session, the team-members rather worked individually, often in opposite areas of the board without being able to see or being interested in each other's contributions, which is detrimental to idea-building. About 50\% of the participants acknowledged in the survey, that they didn't notice the other participants. Only a third said, yes, they did pay attention to the ideas of the others, but about $80 \%$ of the participants mentioned, they couldn't build on the ideas of the others. 


\section{Brazilian \\ Creative Industries}

Since the outcome of creativity in teams heavily relies on idea building, more research is needed to develop CT encouraging active collaboration.

\section{CONCLUSIONS}

As for the theoretical contribution, this work shows that creative collaboration in ad hoc teams utilizing virtual CT is not only feasible but also effective. Previous findings on the need for goal and task clarity (task connection) for successful virtual teamwork are substantiated.

Besides, the virtual usability of three respective CT was evaluated in detail, contributing to the research of CT and creativity in general. With the focus on the key factors of production-blocking and evaluation-apprehension during ideation, the findings contribute to the further development of CT to be applied in VT.

In addition, the desired effect of the consecutive ideas seems to be more difficult to achieve in VT than in analog teams. This may be due to the participants' lack of experience with the creative techniques and/or with the technical requirements of VT sessions. However, this shortcoming could be remedied by a leading moderation of the meetings and a more intensive training of the participants.

As the key part of this research was an experiment, several limitations need to be considered. Despite thorough care to recreate realistic situations, the experiment conducted was still done so under laboratory conditions. Therefore, the transferability is not warranted. To securely verify the findings, a colocated control-group, using the same CT would be required.

Also, the sample is a mere convenience sample, not reflecting the population mean. Taking the variety of social backgrounds of the participants into account, the results might be completely different from another sample.

Lastly, the experimental results were in fact compared with each other, lacking a tangible reference point. Therefore, these findings need to be evaluated again utilizing precise control groups.

\section{SUGGESTIONS FOR FUTURE RESEARCH}

Within the framework of this work, only three CT were tested. Based upon the results in consideration to the classification of the CT used, more CT should be tested and evaluated, and adapted to virtual usability. A focal point in that research should be the aspect of idea-building and how to get participants to interact more. The results of the experiment led to the assumption, that the more intuitive, imaginative a technique is, the more inviting to break existing paradigms and think outside the box it is, the more unique 


\section{Brazilian Creative Industries}

ideas are possible. Nevertheless, the data collected is too insubstantial to fully confirm this hypothesis. Further research on this topic is suggested.

\section{SUMMARY}

This paper aims to examine the acceptance and usability of creativity techniques in a virtual workspace. As a first step, a theoretical framework based on current literature is established. The characteristics of teams and especially virtual teams are examined, as well as the key aspects and attributes of creativity and - again - team creativity.

An experiment was conducted, assessing three selected CT using a virtual whiteboard. The reception of the CT in combination with using a virtual whiteboard as workspace, was assessed through an anonymous online-survey.

Putting the emphasis on establishing distinct task and goal clarity during the introduction to the experiment, creativity techniques as well as the whiteboard were well accepted, leading to a large number of ideas during the experimental ideation sessions. The effective use - measuring the outcome of the creative sessions in consideration of the number of ideas collected, was proven. The efficacy is still questionable, as the quality of the ideas has not been evaluated.

The findings of this work are to be considered as a first step leading to a deeper and more detailed research. Initially, to evaluate how to embed the concept of Swift Trust in a beneficial way for ad hoc teams to be able to work together faster. Secondly, how creativity techniques might be adapted to a digital workspace and the use in virtual teams, keeping in mind non-distracting usability, and - as the findings have revealed: to have a bit of fun in ideation.

\section{REFERENCES}

ADAMS, B. D.; WALDHERR, S.; SARTORI, J.; THOMSON, M. Swift Trust in Distributed Ad Hoc Teams. 2007.

AMABILE, T. M. Creativity in context: Update to the social psychology of creativity. Westview Press, 1996.

AMABILE, T. M. Componential Theory of Creativity. In: KESSLER, E. H. (Ed.). Encyclopedia of Management Theory. Sage Publications, 2013, pp. 134-139.

BECKER, J. H. Kreativitätstechniken. In: BECKER, J. H.; EBERT, H.; PASTOORS, S. (Eds.). Praxishandbuch berufliche Schlüsselkompetenzen. Springer Berlin Heidelberg, 2018, pp. 89-102. 


\section{Brazilian \\ Creative Industries}

BEYERLEIN, M.; HAN, S. J.; PRASAD, A. A Multilevel Model of Collaboration and Creativity. Team Creativity and Innovation, 195-224. 2018.

BJØRN, P.; NGWENYAMA, O. Virtual team collaboration: building shared meaning, resolving breakdowns and creating translucence. Information Systems Journal, 19(3), 227-253. 2009.

CHAMAKIOTIS, P. Factors Influencing Creativity in Virtual Design Teams. In: ASME 2011. International Design Engineering Technical Conferences (IDETC) and Computers and Information in Engineering Conference (CIE). Washington (DC), USA. 2011.

CHAMAKIOTIS, P. Exploring Creativity in Temporary Virtual Teams: The Case of Engineering Design. [Doctoral Work]. University of Bath, 2014.

CHAMAKIOTIS, P.; DEKONINCK, E.; PANTELI, N. Creativity in Virtual Design Teams. INTERNATIONAL DESIGN CONFERENCE - DESIGN 2010. Dubrovnik, Croatia. 2010.

CHANG, C. M. New organizational designs for promoting creativity: A case study of virtual teams with anonymity and structured interactions. Journal of Engineering and Technology Management, 28(4), 268-282. 2011.

CSIKSZENTMIHALYI, M. The Systems Model of Creativity. (SOFTCOVER reprint OF). SPRINGER, 2016.

DAIM, T. U.; HA, A.; REUTIMAN, S.; HUGHES, B.; PATHAK, U.; BYNUM, W.; BHATLA, A. Exploring the communication breakdown in global virtual teams. International Journal of Project Management, 30(2), 199-212. 2012.

FURMANEK, L.; DAURER, S. Application of Media Synchronicity Theory to Creative Tasks in Virtual Teams Using the Example of Design Thinking. $14^{\text {th }}$ International Conference on Wirtschaftsinformatik. 2019.

GABRIEL, A.; MONTICOLO, D.; CAMARGO, M.; BOURGAULT, M. Creativity support systems: A systematic mapping study. Thinking Skills and Creativity, 21, 109-122. 2016.

GAUBINGER, K.; RABL, M.; SWAN, S.; WERANI, T. Creativity Techniques. In: GAUBINGER, K.; RABL, M.; SWAN, S.; WERANI, T. (Eds.). Springer Texts in Business and Economics. Innovation and Product Management, pp. 115-133. Springer Berlin Heidelberg. 2015.

GAWLAK, M. Kreativitätstechniken im Innovationsprozess: Von den klassischen Kreativitätstechniken hin zu webbasierten kreativen Netzwerken. Diplomica-Verlag, 2014. 


\section{Brazilian \\ Creative Industries}

GESCHKA, H. Kreativitätstechniken und Methoden der Ideenbewertung. In: SOMMERLATTE, T.; BEYER, G. (Eds.). Innovationskultur und Ideenmanagement: Strategien und praktische Ansätze für mehr Wachstum. 1st ed., pp. 217-249. Symposion, 2006.

JARVENPAA, S. L.; LEIDNER, D. E. Communication and Trust in Global Virtual Teams. (10), Article 6, $791-$ 815. 1999.

LEOPOLDINO, K. D. M.; GONZÁLEZ, M. O. A.; FERREIRA, P. D. O.; PEREIRA, J. R.; SOUTO, M. E. C. Creativity techniques: a systematic literature review. Product Management \& Development, 14(2), 95-100. 2016.

MADUKA, N. S.; EDWARDS, H.; GREENWOOD, D.; OSBORNE, A.; BABATUNDE, S. O. Analysis of competencies for effective virtual team leadership in building successful organisations. Benchmarking: An International Journal, 25(2), 696-712. 2018.

NEMIRO, J. Creativity in Virtual Teams: Key Components for Success. Collaborative Work Systems Series, v. 6. John Wiley \& Sons Inc. 2004.

NEMIRO, J. Creativity techniques for virtual teams. In: The handbook of high-performance virtual teams: a toolkit for collaborating across boundaries. Jossey-Bass, 2008, pp. 491-531.

NESS, I. J.; DYSTHE, O. Polyphonic Imagination: Understanding Idea Generation in Multidisciplinary Groups as a Multivoiced Stimulation of Fantasy. Creativity Research Journal, 32(1), 30-40. 2020.

OCKER, R. J. Creativity in Asynchronous Virtual Teams: Putting the Pieces Together. In: MACGREGOR, S. P.; TORRES-CORONAS, T. (Eds.). Higher Creativity for Virtual Teams. IGI Global, 2007, pp. 26-47.

PASTOORS, S. Kreativität. In: BECKER, J. H.; EBERT, H.; PASTOORS, S. (Eds.). Praxishandbuch berufliche Schlüsselkompetenzen. Springer Berlin Heidelberg, 2018, pp. 81-88.

PAULUS, P. B.; COSKUN, H. Group Creativity. In: Encyclopedia of Creativity. Elsevier, 2020, pp. 562-568.

PAULUS, P. B.; DZINDOLET, M.; KOHN, N. W. Collaborative Creativity-Group Creativity and Team Innovation. In: Handbook of Organizational Creativity. Elsevier, 2012, pp. 327-357.

TORRES-CORONAS, T.; GASCO-HERNANDEZ, M. Improving Virtual Teams through Creativity. In: KISIELNICKI, J. (Ed.). Virtual Technologies. IGI Global, 2008, pp. 1679-1686.

VREEDE, T. de; BOUGHZALA, I.; VREEDE, G.-J. de; REITER-PALMON, R. The Team Creativity Model: An Exploratory Case Study. Journal of the Midwest Association for Information Systems, 2017(1), 19-34. 2017. 